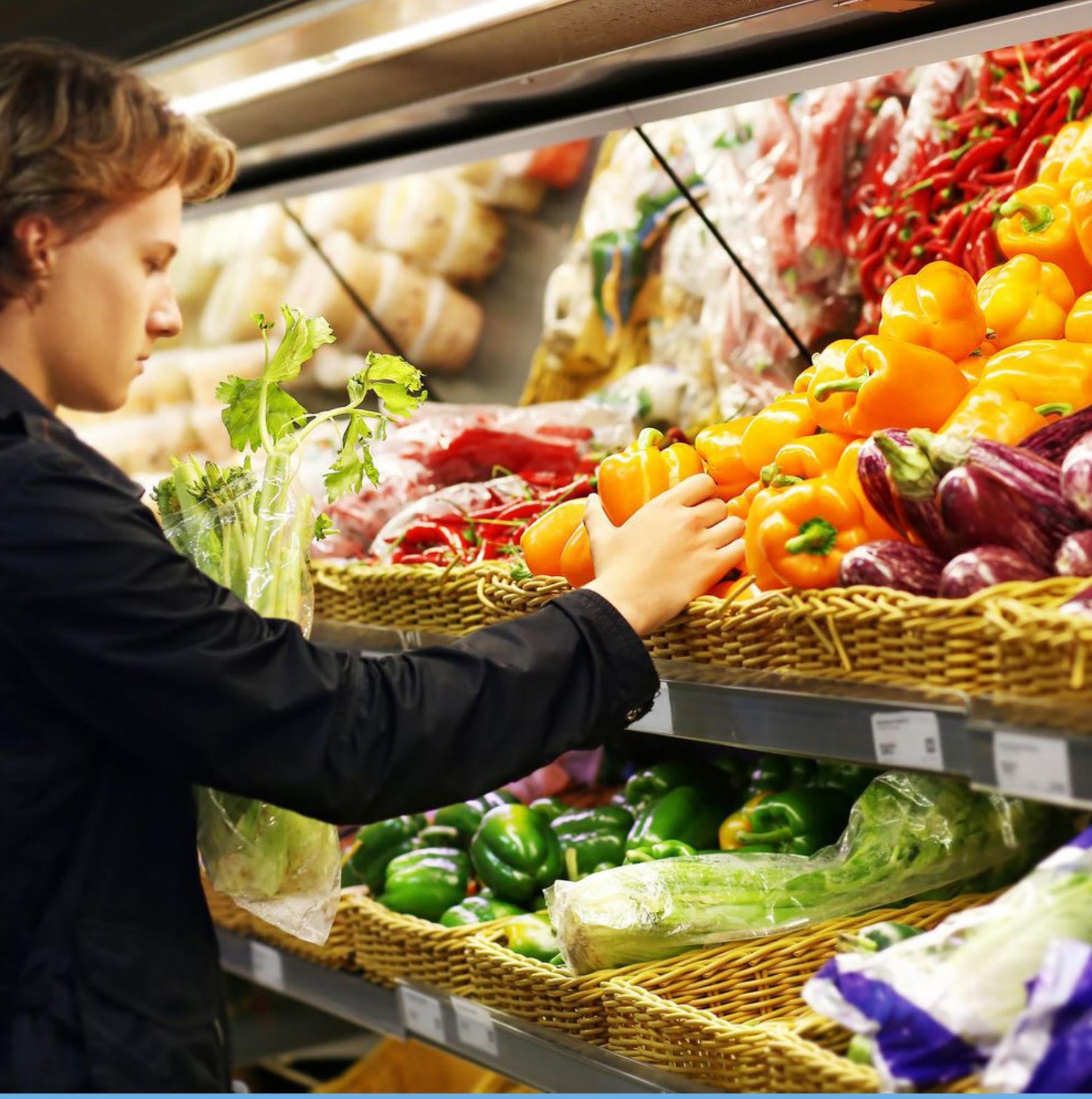

Vernevelingstechniek op het supermarkt schap

in relatie tot kwaliteit en houdbaarheid

Hilke Bos-Brouwers, Damir Huromevic 



\section{Vernevelingstechniek op het supermarktschap in relatie tot kwaliteit en houdbaarheid}

Auteurs: Hilke Bos-Brouwers, Damir Huromevic

Instituut: Wageningen Food \& Biobased Research

Dit onderzoek is uitgevoerd door Wageningen Food \& Biobased Research in opdracht van Vakcentrum en gefinancierd door Vakcentrum, TKI Topsector Agrifood, in het kader van PPS Houdbaarheid Begrepen (projectnummer TKI-AF-15291).

Wageningen Food \& Biobased Research

Wageningen, oktober 2018

Openbaar

Rapport 1973

ISBN 978-94-6395-106-7,

DOI: https://doi.org/10.18174/499086 
Versie: definitief

Reviewer: Anke Janssen

Goedgekeurd door: Nicole Koenderink

Opdrachtgever: Vakcentrum

Financier: Vakcentrum, TKI Topsector Agrifood

Dit rapport is gratis te downloaden op / of op www.wur.nl/wfbr (onder publicaties).

(C) 2019 Wageningen Food \& Biobased Research, instituut binnen de rechtspersoon Stichting Wageningen Research.

Het is de opdrachtgever toegestaan dit rapport integraal openbaar te maken en ter inzage te geven aan derden. Zonder voorafgaande schriftelijke toestemming van Wageningen Food \& Biobased Research is het niet toegestaan:

a. dit door Wageningen Food \& Biobased Research uitgebrachte rapport gedeeltelijk te publiceren of op andere wijze gedeeltelijk openbaar te maken;

b. dit door Wageningen Food \& Biobased Research uitgebrachte rapport, c.q. de naam van het rapport of Wageningen Food \& Biobased Research, geheel of gedeeltelijk te doen gebruiken ten behoeve van het instellen van claims, voor het voeren van gerechtelijke procedures, voor reclame of antireclame en ten behoeve van werving in meer algemene zin;

c. de naam van Wageningen Food \& Biobased Research te gebruiken in andere zin dan als auteur van dit rapport.

Postbus 17, 6700 AA Wageningen, T 03174800 84, E info.wfbr@wur.nl, www.wur.nl/wfbr. Wageningen Food \& Biobased Research is onderdeel van Wageningen University \& Research.

Alle rechten voorbehouden. Niets uit deze uitgave mag worden verveelvoudigd, opgeslagen in een geautomatiseerd gegevensbestand of openbaar gemaakt in enige vorm of op enige wijze, hetzij elektronisch, hetzij mechanisch, door fotokopieën, opnamen of enige andere manier, zonder voorafgaande schriftelijke toestemming van de uitgever. De uitgever aanvaardt geen aansprakelijkheid voor eventuele fouten of onvolkomenheden. 


\section{Inhoud}

Woord vooraf

1 Inleiding

2 Methoden

3 Resultaten

4 Discussie en vragen voor vervolgonderzoek

Literatuur 


\section{Woord vooraf}

\section{Vakcentrum \& PPS Houdbaarheid Begrepen}

Het Vakcentrum is de brancheorganisatie van zelfstandige detaillisten in food, non-food, fast moving consumer goods en franchisenemers. De missie van het Vakcentrum is om MKB-winkeliers en franchisenemers te verbinden, vertegenwoordigen en mobiliseren om hun ondernemerschap, zelfstandigheid en verdienkracht te borgen en daarmee de leefbaarheid van de samenleving te vergroten. Het Super Supermarkt Keurmerk (SSK) is in 2012 ontwikkeld door Vakcentrum in samenwerking met kennisinstituut TNO. Met het SSK Keurmerk ondersteunt en stimuleert Vakcentrum haar supermarktleden bij het invulling geven aan maatschappelijk verantwoord ondernemen. Het SSK keurmerk staat voor lokaal en maatschappelijk betrokken ondernemerschap.

Het tegengaan van voedselverspilling is een belangrijk thema voor ondernemers die zijn aangesloten bij het Vakcentrum. Het reduceren van voedselverspilling is het hoogst geprioriteerde verduurzamingsdoel voor ondernemers uit de foodsector, zo blijkt uit het Vakcentrum ledenonderzoek duurzaamheid. Inzet om verspilling te verminderen komt ook terug binnen de criteria van het SSK keurmerk. Om ondernemers te ondersteunen bij het verminderen van voedselverspilling, initiëren het Vakcentrum en de Stichting SSK diverse activiteiten. Zo is een convenant afgesloten met de Vereniging Voedselbanken Nederland om het doneren van producten te vergemakkelijken, worden winkelacties rondom bewustwording georganiseerd (zie ook paragraaf 2.2.) en is Vakcentrum aangesloten bij relevante netwerken, waaronder het Europese Retailers' Environmental Action Programme (REAP), de Alliantie Verduurzaming Voedsel en MVO Nederland.

Daarnaast zijn het Vakcentrum en de Stichting Super Supermarkt Keurmerk partners in het publiekprivate project 'PPS Houdbaarheid Begrepen'. Doelstelling van dit project is het terugdringen van houdbaarheidsdatum gerelateerde derving op de winkelvloer en verspilling door de consument in de thuisomgeving. Samen met Wageningen University \& Research worden projecten vormgegeven waarmee deze doelstelling wordt bereikt. Eén van deze projecten is de ontwikkeling van dit overzicht over de stand van zaken uit de wetenschappelijke literatuur m.b.t. de inzet van vernevelingstechniek op het supermarkt schap om verspilling (derving) tegen te gaan. Met dit rapport kunnen het Vakcentrum en haar leden gebruik maken van de meest recente informatie over dit onderwerp, ter inspirate voor het verminderen van voedselverspilling op de winkelvloer.

De inhoud van dit rapport is tot stand gekomen binnen het publiek-private samenwerkingsproject Houdbaarheid Begrepen, dat mede wordt gefinancierd door het Ministerie van LNV via de TKI Topsector Agri-Food. Vakcentrum is partner in dit project, waarbij zij samen met Wageningen Food \& Biobased Research optrekken om houdbaarheid gerelateerde voedselverspilling op het supermarkt schap en bij de consument thuis terug te dringen. De ontwikkeling van effectieve interventies in de interactie tussen de supermarkt en de consument staan centraal in dit project. De houdbaarheidsdatum wordt door levensmiddelenproducenten op een product geplaatst conform verordening (EU) 1169/2011. Naast redenen van voedselveiligheid, speelt ook mee tot wanneer de producent de kwaliteit van het product kan en wil garanderen. Het kan dan bijvoorbeeld gaan om smaak en textuur eigenschappen van het product.

Bij de bepaling van de termijn voor houdbaarheid wordt ook rekening gehouden met een veiligheidsmarge. In de praktijk kan dit ertoe leiden dat producten van goede kwaliteit uit de schappen worden gehaald (dan wel worden afgeprijsd) of door de consument worden verspild. Bij de verspilling door de consument spelen het kennisniveau, motivatie en gedragsaspecten een belangrijke rol. 
Het rapport over Vernevelingstechniek past binnen dit project doordat het supermarkten een handvat geeft om nieuwe opties voor het voorkomen van derving middels het tegengaan van kwaliteitsverlies van verse groenten en fruit te overwegen. De voorgespiegelde technische opties zijn veelal zichtbaar aanwezig voor klanten, waardoor er gelegenheid ontstaat om deze te informeren over het behoud van kwaliteit en het belang van het terugdringen van voedselverspilling. Hiermee kan het bewustzijn van consumenten worden vergroot. 


\section{Inleiding}

De doelstelling van de PPS Houdbaarheid Beter Begrepen is het terugdringen van houdbaarheidsdatum gerelateerde derving op de winkelvloer en verspilling door de consument in de thuisomgeving. Dit project draagt bij aan het ontwikkelen van effectieve interventies in interactie tussen de supermarkt en de consument. Vakcentrum is partner in het projectconsortium en heeft als onderzoeksvraag ingebracht hoe vernevelingstechniek kan worden ingezet om kwaliteit en houdbaarheid van versproducten op het supermarkt schap positief te beïnvloeden om derving in de retail te verminderen. Dit deelonderzoek draagt bij aan het vergroten van kennis en inzicht rondom bewaring van verse producten.

Vernevelingstechniek is een techniek waarbij een droge/ultrasone 'mist' door middel van een vernevelaar ingezet wordt. Naast 'droge mist' bestaan er ook vernevelaars die zogenoemde "natte" mist verspreiden, waardoor het product op het schap ook vochtig wordt/aanvoelt.

Het principe achter deze techniek is het beïnvloeden van het vochtigheidsgehalte in de direct omgeving van het uitgestalde product. Kwaliteitsbehoud kan dan worden bereikt via het mechanisme dat 'uitdroging' oftewel vochtverlies uit het product vertraagt. Deze 'uitdroging' is een van de bepalende factoren van kwaliteitsverlies van versproducten en heeft ook invloed op de perceptie van de consument op de 'versheid' van een product. Bij het langer vasthouden van een bepaalde, gewenste kwaliteit, wordt de houdbaarheid ervan verlengt. Dit heeft een gunstige invloed op het voorkomen van voedselverspilling, doordat het stock-management beter georganiseerd kan worden.

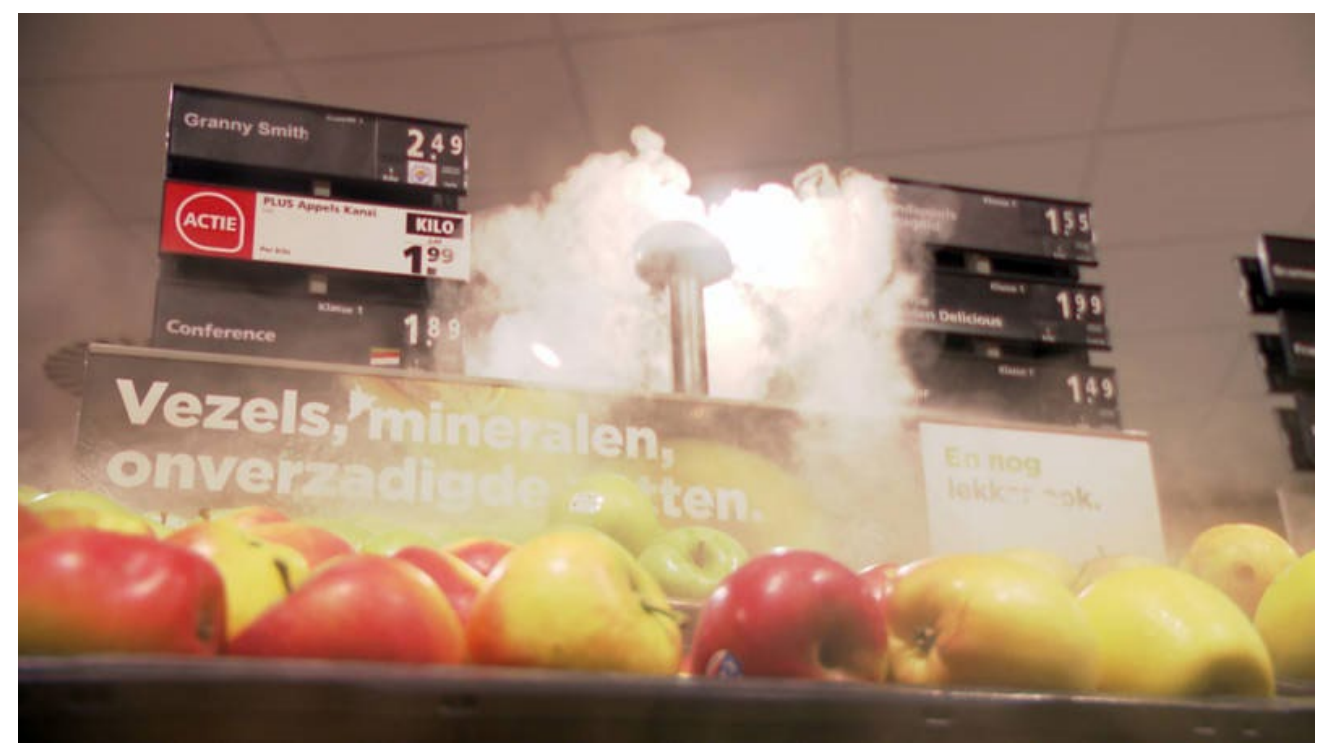

Figuur 1: Illustratie van inzet van verneveling op het supermarkt schap. Bron:

https://nos.nl/artikel/2181144-mist-houdt-groente-en-fruit-langer-goed-in-supermarkt.html

De techniek is op zichzelf niet nieuw. Al enkele decennia kun je het tegenkomen in supermarkten. In Nederland is er op dit moment een handjevol supermarkten die het toepassen. In landen als VS, Frankrijk, Duitsland en UK is de kans groot dat je het als klant tegenkomt. Door de toenemende aandacht voor het voorkomen van voedselverspilling in de hele keten van boer tot en met consument, onder andere neergelegd in de nieuwe nationale agenda tegen voedselverspilling die op 20 maart 2018 is gelanceerd, is het opportuun om het inzetten van deze techniek (opnieuw) onder de loep te nemen.

Dit onderzoek heeft als doel om verslag te doen van de huidige stand van zaken van vernevelingstechniek op het supermarkt schap, zoals dat beschreven wordt in de wetenschappelijke 
literatuur. Het richt zich op versproducten uit de AGF categorieën, waarbij de focus ligt op niet-gekoelde uitstalling.

De gehanteerde onderzoeksvragen zijn:

- Hoe kan vernevelingstechniek worden ingezet als techniek om KWALITEIT te behouden (en daarmee de HOUDBAARHEID te verlengen) van versproducten op het supermarkt schap?

- Welke achterliggende aspecten rondom PERCEPTIE bij klanten/consumenten spelen mee bij de inzet van vernevelingstechniek op het supermarkt schap?

Het onderzoek is uitgevoerd als een deskstudie binnen wetenschappelijke literatuur en (in beperkte mate) grijze literatuur gedurende de periode september 2017-september 2018. Dit rapport vormt hiervan het verslag. 


\title{
2 Methoden
}

Het onderliggende onderzoek is opgezet als deskstudie. Via diverse wetenschappelijke search engines en via internet zoekmachines is gezocht naar relevante papers en artikelen die ingaan op de onderzoeksvragen van deze rapportage, naar kwaliteit/houdbaarheid verlenging en consumentenperceptie in relatie tot het inzetten van vernevelingstechniek op het supermarkt schap.

\section{Gebruikte zoektermen zijn onder andere (in ENGELS):}

Humidification of vegetables

Vegetables Ultrasonic Humidifier

Dry fog

Nano-scale mist

Ultrasonic fogging system with water/air ozonation

Dry mist technology

Retail fogging

Groceries misting

Moisturising vegetables in retail

Evaporative cooling

Zowel als zelfstandige zoekterm, als in combinatie met 'supermarket', 'retail' en 'consumer'

\author{
Search engines die ingezet zijn: \\ Scopus \\ Sciencedirect.com \\ Researchgate.com \\ WUR online library \\ Google Scholar/Google
}

\section{Korte samenvatting van de Literature Search en beperkingen}

$\mathrm{Er}$ is maar in beperkte mate relevant wetenschappelijk onderzoek te vinden in de (internationale) peer-reviewed literatuur die de technische aspecten van verneveling door vertaald naar toepassingen rondom kwaliteit en houdbaarheid verlenging op het supermarktschap.

Er zijn slechts in zeer beperkte mate artikelen aangetroffen die ingaan op de perceptie van de consument op inzet vernevelingstechniek op het supermarkt schap. Er bestaan daarentegen veel studies over consumentengedrag in supermarkten. Deze inzichten van meer algemene aard zijn wel meegewogen, maar vallen in principe buiten de scope van het onderzoek.

Studies die alleen ingingen op de (inregel)techniek zelf, of in andere toepassingen zijn gebruikt (zoals bijvoorbeeld bewaring in distributiecentra of andere opslag) zijn niet meegenomen in dit onderzoek.

Daarnaast werden diverse media-artikelen aangetroffen, die veelal opiniestukken betreffen over het wel of niet inzetten van verneveling. Deze waren regelmatig verwoord als zorgen die klanten kunnen hebben over voedselveiligheid of nut van deze techniek op het schap. Omdat het hier geen wetenschappelijke studies betreft, zijn deze ter kennisgeving aangenomen, maar hiervan wordt geen verslag gedaan in dit rapport.

Wageningen Food \& Biobased Research heeft in 2009-2010 bewaar-technisch onderzoek uitgevoerd naar inzet van vernevelingstechniek onder opslagcondities. Dit onderzoek is onder gecontroleerde omstandigheden in de koelcellen van het instituut uitgevoerd. Hoewel het geen test op het supermarkt schap betreft, zijn de bevindingen wel opgenomen in de rapportage, omdat hieruit vervolgonderzoek dat wel in de supermarkt plaatsvond is voortgekomen (Fresh Demo project). 


\section{Over vernevelingstechniek}

Er bestaan grofweg 2 verschillende vernevelingstechnieken, die droge of natte 'mist' produceren. Natte mist bevat relatief grote(re) waterdruppeltjes, die verkregen worden door terug koelen van stoom of via 'nozzles'. Deze nozzles 'besproeien' de producten, gebruikmakend van compressie en hoge druk. Bij natte mist is het daadwerkelijk zo dat de benevelde producten nat/vochtig worden. Dit is meteen het belangrijkste verschil met droge mist, die verkregen wordt via ultrasoon technieken, waarbij de mist al is verdampt voordat het de producten raakt. Daarmee wordt alleen de luchtvochtigheid in de nabije omgeving verhoogd, terwijl de producten niet nat worden. De systemen kennen verschillende waarden voor water- en energiegebruik. Uit de gebruikte literatuur kan met voorbehoud worden gesteld dat dit gebruik lager ligt bij het toepassen van droge mist. 


\section{Resultaten}

Deze sectie geeft een overzicht van de gevonden resultaten uit de literatuur studie. Eerst komen de gevonden referenties met betrekking tot de technologische aspecten rondom kwaliteit en houdbaarheidsverlenging aan bod. In de tweede paragraaf wordt dieper ingegaan op de perceptie van consumenten op de inzet van vernevelingstechniek op het supermarkt schap. Zo veel mogelijk wordt de structuur aangehouden van laboratoriumschaal naar (al dan niet grootschalige) implementatie in de praktijk.

\subsection{Kwaliteit \& Houdbaarheid}

Deze sectie gaat in op de stand van zaken in de literatuur in antwoord op de volgende onderzoeksvraag:

Hoe kan vernevelingstechniek worden ingezet als techniek om KWALITEIT te behouden (en daarmee de HOUDBAARHEID te verlengen) van versproducten op het supermarkt schap?

Per gerefereerde studie wordt ingegaan op de gehanteerde definities van kwaliteit, de onderzochte producten en de resultaten die worden beschreven rondom kwaliteit en houdbaarheidsverlenging in de context van het uitgevoerde onderzoek. Daarnaast wordt aandacht gegeven aan gerapporteerde voor- en nadelen van de inzet van deze techniek.

\subsubsection{Laboratorium schaal}

\section{Verschoor, J. \& Otma, E., 2010. Evaluation of Contronics "fresh in - fresh out" fresh} displays. Report no. 1190.

In 2009-2010 voerden een aantal onderzoekers van Wageningen Food \& Biobased Research onderzoek uit naar het inzetten van de droge mist vernevelingstechniek van Contronics (zie ook Fresh Demo) wat voortborduurde op de uitkomsten van dit onderzoek). In deze studie voerden de onderzoekers een onafhankelijk onderzoek uit naar de "Fresh in-Fresh Out" technologie van Contronics, gebaseerd op droge mist. Voorlopers van deze techniek waren de "sanifogger" en 'travelfogger", die doorontwikkeld zijn in een systeem dat zorgt voor bevochtiging onder niet-gekoelde bewaarcondities voor groenten en fruit.

Drie displays zijn getest ${ }^{\circ}$

1) "Normaal": op het schap bij $20^{\circ}$ Celcius

2) "Teruggekoeld" (Re-cooling): normaal display, maar die 's nachts in een koelcel werden bewaard bij $8^{\circ}$ Celsius

3) "Contronics": display onder gestandaardiseerde supermarkt condities, met gebruikmaking van de vernevelingstechniek, zonder nachtelijke terug koeling.

De foto in figuur 2 hieronder laat de onderzoeksopzet in de bewaarfaciliteit van Wageningen Food \& Biobased Research zien. Vooraan staat de Contronics installatie, daarachter 're-coling' en helemaal achterin het normale schap. 
De geteste producten zijn:
- Bospeen
- Tomaten
- Druiven
- Bananen
- Witlof
- Sperziebonen
- Kropsla

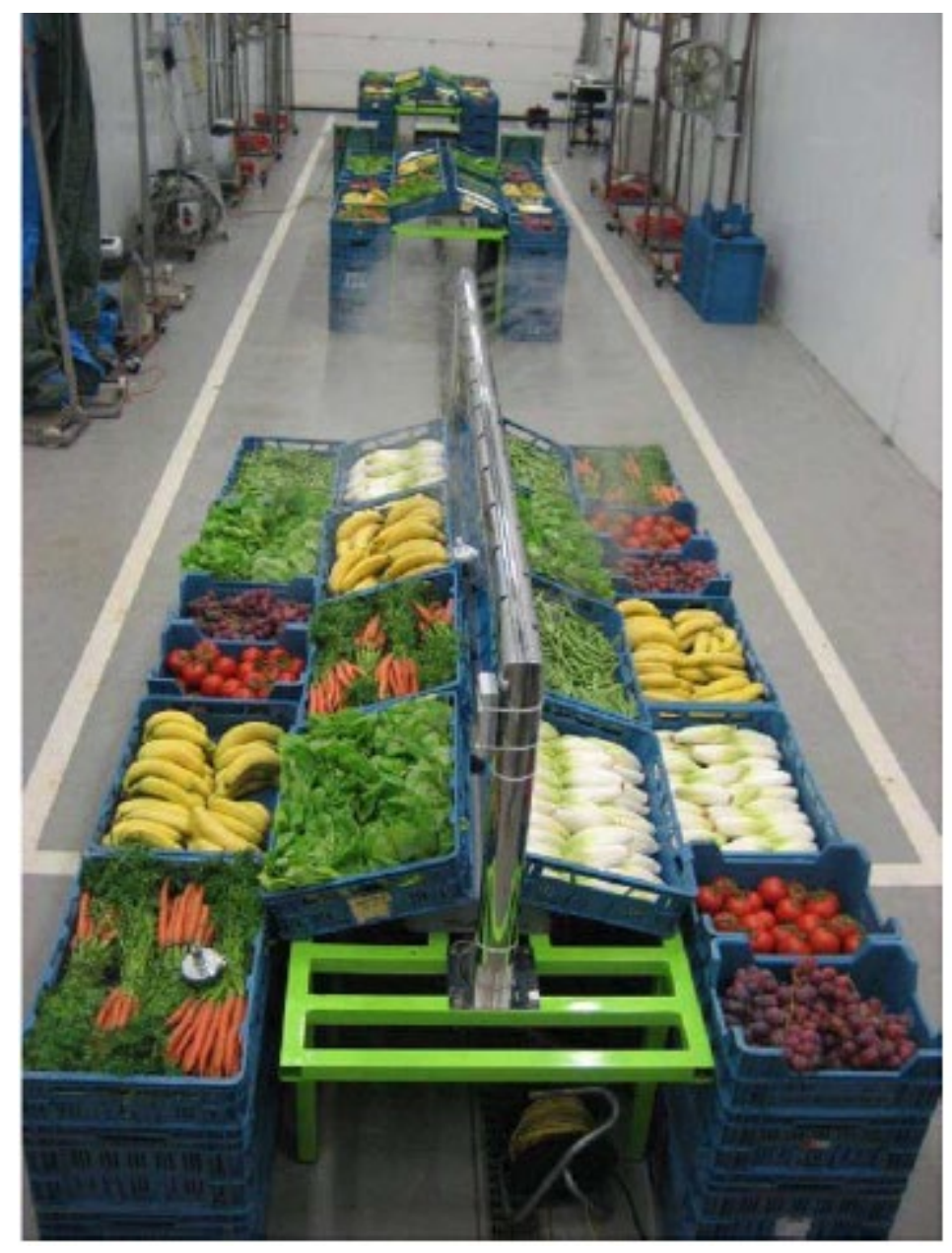

Figuur 2: Opstelling bewaartest. Bron: Verschoor \& Otma, 2010 
Naast de kwaliteitsbeoordeling, is ook water uit het vernevelingsysteem getest op de aanwezigheid van Legionella door een gecertificeerd laboratorium. Onderzochte kwaliteitsaspecten over een gestandaardiseerde meetperiode van 48 uur waren:

1. Gewichtsverlies/vochtverlies

2. Verkleuring

3. Stevigheid

De resultaten van het onderzoek wijzen uit dat bij het schap waarbij de vernevelingstechniek is ingezet positieve impact op de kwaliteit van de versproducten is gevonden. Het effect betreft voornamelijk het beperken van gewichtsverlies ten aanzien van de normale uitstalling. Het vertragen van vochtverlies kan gerelateerd worden aan kwaliteitsaspecten zoals betere stevigheid, minder 'rimpels' en verminderde uitdroging. Met verneveling 'presteert' even goed of zelfs beter dan 's nachts terug koelen, waardoor in principe ook bespaard kan worden op arbeidskosten/kosten. Producten hoeven namelijk niet meer in- en uit de koeling/van en naar het schap verplaatst te worden gedurende de nacht.

De onderzoekers geven aan dat de resultaten niet zondermeer door vertaald kunnen worden naar derving de praktijk: veel blijft context afhankelijk, en ook afhankelijk van de ingaande kwaliteit van de producten. Daarnaast maken de onderzoekers het voorbehoud dat het bevochtigingsniveau correct moet worden afgesteld. Wanneer het gehalte te hoog wordt, worden producten en uitstal verpakking nat, wat mogelijk negatieve effecten kan hebben op de productkwaliteit.

Bij alle geteste producten was het vochtverlies (gewichtsverlies) beduidend minder voor de benevelde producten ten opzichte van de normaal-conditie. Ten aanzien van andere kwaliteitseigenschappen werd geen verschil gevonden bij witlof en bananen. Bij 's nachts terug koelen werd wel verschil in vochtverlies gemeten, maar minder verschillen op de andere kwaliteitsaspecten.

Onder de genoemde testomstandigheden bleek dat de vernevelingstechniek bijdraagt aan het behoud van gewicht en kwaliteit. De techniek kan het inzetten van nachtelijke terug koeling vervangen zonder kwaliteitsverlies. 


\section{Ultrasone nevel houdt groente en fruit fris}

In supermarkten in Frankrijk en Duitsland staan ze al: nevelgeneratoren die versproducten als groenten en fruit omhullen in een feeërieke mist. 'Consumenten vinden het geweldig', zegt Jan Verschoor van Food \& Biobased Research. 'En dat zien de supermarkten terug in de verkoop. Maar minstens zo belangrijk is dat deze installaties groenten en fruit langer goed houden.'

Een nevelgenerator bestaat uit een trillend plaatje dat in een reservoir in contact komt met water. Door de ultrasone trillingen valt het water in ragfijne druppeltjes uit elkaar. Een door een ventilator opgewekte luchtstroom voert die fijne mist via buizen weg en blaast het over de producten. Die blijven daardoor langer vochtig en vers.

Verschoor en zijn Wageningse collega's onderzochten voor Contronics, een Nederlandse producent van nevelgeneratoren, de effecten op onder meer de houdbaarheid van groenten, fruit en salades. Met goed gevolg. Er zijn al een paar supermarkten in Nederland met nevelgeneratoren, en als het aan Contronics ligt worden dat er snel meer. De uitkomsten van het Wageningse onderzoek waren minder positief voor de cateringsector. 'De catering mag verse producten in saladebars slechts twee uur uitstallen', zegt

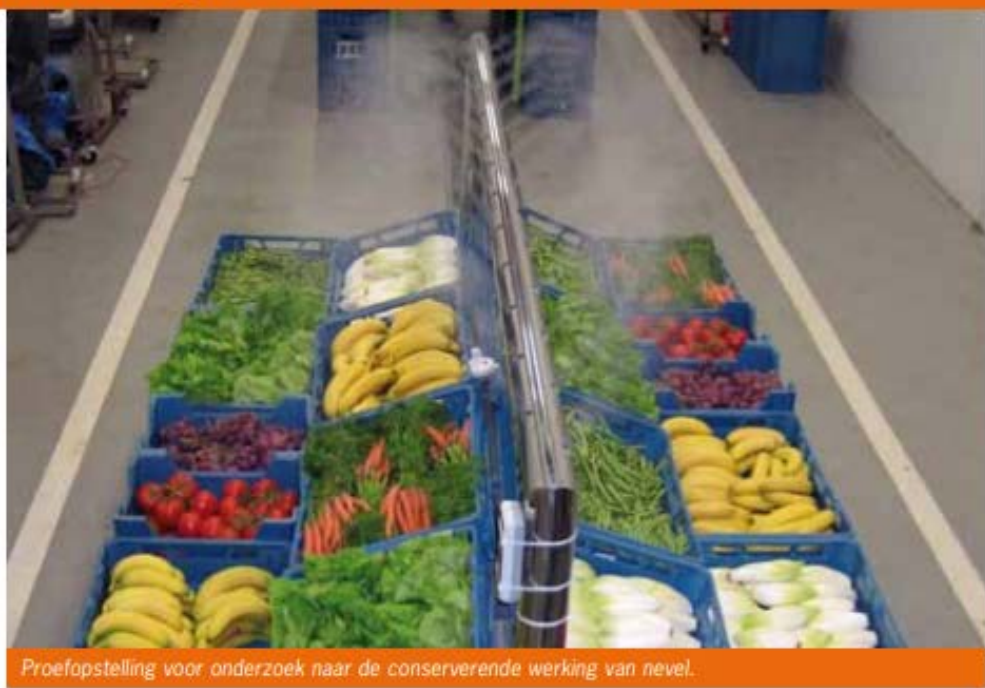

Verschoor. 'Daarna moet je ze volgens de wettelijke richtlijnen weggooien.' Door die restrictie is daar het conserverende effect van nevelgeneratoren verwaarloosbaar. Dat wil echter niet zeggen dat de catering niets aan vernevelaars heeft. "Nevel verhoogt de aantrekkelijkheid van het product', zegt Verschoor. 'Het lokt mensen.'

Supermarkten die groenten en fruit bewaren hebben minder strikte bewaartijden, en kunnen met nevel de houdbaarheid daarvan wel merkbaar verlengen. Hoelang precies kan Verschoor niet zeggen. 'Dat hangt af van het product en de omstandigheden. Maar een bos wortels die na twee dagen zou zijn verschrompeld kan dankzij een vernevelaar nog helemaal fris zijn.'

$\begin{array}{ll}\text { Contact: } & \text { jan.verschoor } 9 \text { wur.nl } \\ & 0317.481293\end{array}$

Figuur 3: Ultrasone nevel houdt groente en fruit fris (Bron: Kennisonline, april 2011: http://edepot.wur.nl/165739)

In het onderzoek worden geen specifieke uitspraken gedaan over de duur van de houdbaarheidsverlenging.

\section{Tirawat, D., Flick, D., Mérendet, V., Erens, E., Laguerre, O., 2017. Combination of fogging and refrigeration for white asparagus preservation on vegetable stalls. Postharvest biology and technology, vol. 124, pp. 8-17.}

Deze studie onderzocht het effect van verneveling en de inzet van koude-plaat koeling op de bewaarkwaliteit van witte asperge op het groenten schap. Verdeeld over 2 testgroepen (verneveling, verneveling + koeling) en 1 controlegroep (conventioneel) werd gekeken naar kwaliteitsbehoud en vochtverlies. De studie is uitgevoerd onder gecontroleerde condities in de koel faciliteiten van het Technical Fruit and Vegetable Center in Parijs. De producten werden naoogst met gekoeld transport naar dit center gebracht, waarna ze koud bewaard werden ( $5^{\circ}$ Celsius) tot het inzetten van de experimenten de dag erna. 
Onderstaande foto (fig.4) laat de asperges zien uit de 3 groepen na 72 uur bewaren:

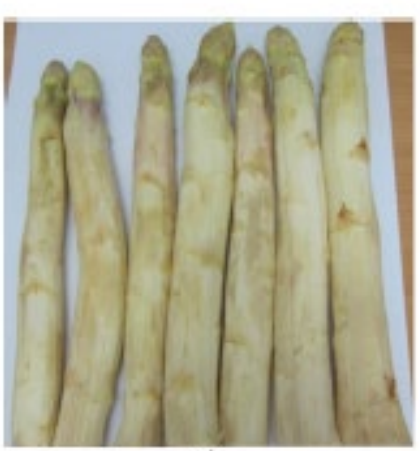

a)

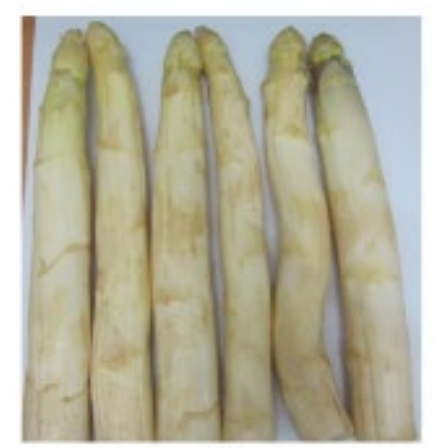

b)

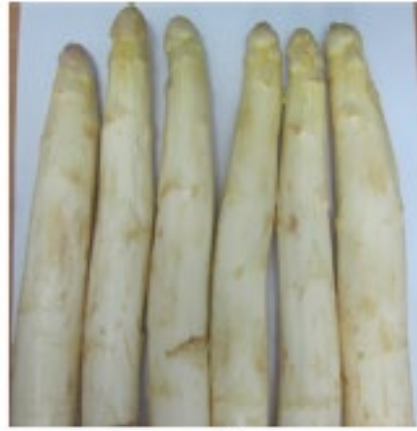

c)

Figuur 4: Voorbeeld uit het onderzoek, asperges uit de 3 groepen na 72 uur bewaren. a) controle groep, b) verneveling, c) verneveling + koeling.

Bron: Tirawat et al., 2017

Uit deze studie blijkt dat het gecombineerd inzetten van koelen en vernevelen het minste vochtverlies en beter behoud van kwaliteit oplevert. Zowel onder de conventionele als de vernevelde uitstalling werd verkleuring (bruinkleuring) van de asperges waargenomen, waar dit bij gecombineerde behandeling pas na 3 dagen optrad.

\subsubsection{Op het schap}

\section{Fresh Demo}

Binnen het Europese H2020 project Fresh Demo dat liep van 2015-2017 werd onderzocht in hoeverre ultrasone humidificatie technologie (droge mist verneveling) in combinatie met een natuurlijke zuurteregelaar (Formule 5, een bioflavonoïde afkomstig uit de schil van Bergamot citrusfruit) kan bijdragen aan het verbeteren van versheid, verlenging van houdbaarheid en hygiënische karakteristieken van fruit en groenten in de hele na-oogstketen van bewaren, transport en het winkelschap (zie voor meer informatie www.fresh-demo.eu en https://vimeo.com/190256796 voor een korte video over dit project), teneinde een bijdrage te leveren aan het verminderen van voedselverspilling. In een van de pilots die binnen dit project zijn uitgevoerd, werd een combinatie van deze technieken ingezet in de praktijk, door Contronics en Plus Van Gurp supermarkt Roosendaal.

Onderstaande foto geeft een beeld van hoe de opstelling van de vernevelingstechniek er ter plaatse van de demonstratie-supermarkt er uit ziet. 


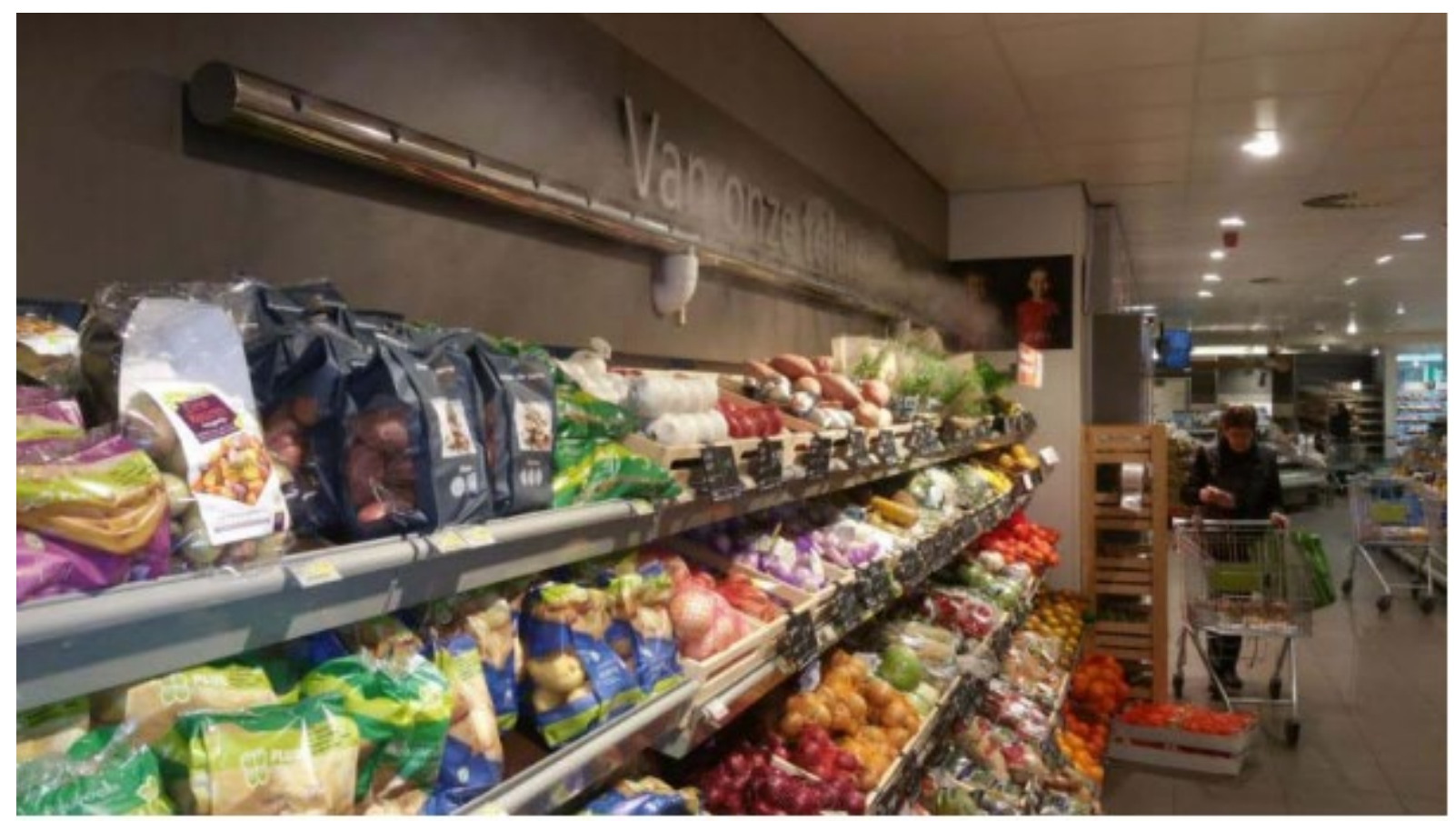

Figuur 5: Opstelling van vernevelingstechniek in een PLUS Van Gurp supermarkt.

Bron: www. Fresh-demo.eu / http://www.contronics.nl/wp-content/uploads/2017/11/fresh-demo-d-4-0official-report-intro-english-.pdf

De producten die getest waren, (en ook behandeld met Formula5) zijn:

Aardbeien uit Huelva (Spanje) (niet bij Plus Van Gurp)

Asperges uit noord Duitsland (niet bij Plus Van Gurp)

Nectarines en wilde perziken uit centraal Italië

Druiven uit zuid Italië

Bloemkool en krulandijvie uit Cambrils (Spanje) (Plus Schijndel)

Opslag van sla in een Spaans distributiecentrum

De geteste producten werden gedurende transport na de oogst, tijdens opslag (waarbij er 2x werd verladen) en het transport naar de supermarkt, koeling ter plekke en op het schap behandelt met de vernevelingstechniek, en vergeleken met een controle groep waarbij de technieken niet werden toegepast. Als extra variabele werd het inzetten van de zuurteregelaar toegevoegd in de onderzoeksopzet. De experimenten zijn 3x uitgevoerd in dezelfde opzet. 
Onderzochte kwaliteitseigenschappen waren:

Vochtverlies

Verlenging houdbaarheid (schap-leven)

Smaak, kleur en visuele kwaliteit

Daarnaast is doorgerekend wat de bijdrage aan het verminderen van derving is (in \% en Euro's omzet). De resultaten werden als volgt weergegeven (fig.6):

\section{Table of results}

\begin{tabular}{|l|c|c|c|c|c|c|c|c|c|c|c|c|c|c|c|c|c|c|c|}
\hline & \multicolumn{3}{|c|}{ strawberies } & \multicolumn{3}{|c|}{ grapes } & \multicolumn{4}{|c|}{ peaches } & \multicolumn{3}{|c|}{ nectarines } & \multicolumn{3}{c|}{ cauliflower } & \multicolumn{2}{c|}{ curly endive } \\
\hline ID & C & H & HD & C & H & HD & C & H & HD & C & H & HD & C & H & HD & C & H & HD \\
\hline weight loss & 1 & 5 & 4 & 1 & 5 & 5 & 1 & 5 & 5 & 1 & 3 & 5 & 1 & 5 & 4 & 1 & 4 & 5 \\
\hline appearance & 1 & 5 & 5 & 1 & 5 & 5 & 1 & 5 & 5 & 1 & 5 & 5 & 1 & 5 & 5 & 1 & 5 & 5 \\
\hline shelf life / mould & 1 & 5 & 5 & 1 & 3 & 5 & 1 & 5 & 5 & 1 & 4 & 5 & 1 & 5 & 5 & 1 & 5 & 5 \\
\hline flavour & 1 & 5 & 3 & 1 & 5 & 5 & 1 & 5 & 5 & 1 & 5 & 5 & 1 & 5 & 5 & 1 & 5 & 5 \\
\hline vitamins & 3 & 5 & 1 & 3 & 1 & 5 & 1 & 4 & 5 & 3 & 1 & 5 & 3 & 1 & 5 & 5 & 1 & 3 \\
\hline Total & $\mathbf{7}$ & $\mathbf{2 5}$ & $\mathbf{1 8}$ & $\mathbf{7}$ & $\mathbf{1 9}$ & $\mathbf{2 5}$ & $\mathbf{5}$ & $\mathbf{2 4}$ & $\mathbf{2 5}$ & $\mathbf{7}$ & $\mathbf{1 8}$ & $\mathbf{2 5}$ & $\mathbf{7}$ & $\mathbf{2 1}$ & $\mathbf{2 4}$ & $\mathbf{9}$ & $\mathbf{2 0}$ & $\mathbf{2 3}$ \\
\hline
\end{tabular}

Different scores show different evaluations

5 points - best results

1 point - worst results

$C=$ Regular transport and storage

$H=$ Humidified transport and storage

$H D=$ Humidified transport and storage; treated with Formula5

Figuur 6: Analyse resultaten FRESH-DEMO Project

Bron: FRESH-DEMO, report D4.0 Report on all Fresh Demo tests, 2017.

Voor alle onderzochte producten werd een betere score gevonden voor de met verneveling behandelde producten ten opzichte van de controlegroep. Op aardbeien na, was de score voor de combinatie van verneveling met de zuurteregelaar over het algemeen nog beter (1-7 punten meer). Producten behandelt met de zuurteregelaar lieten een verwaarloosbare bacteriologische groei zien. 


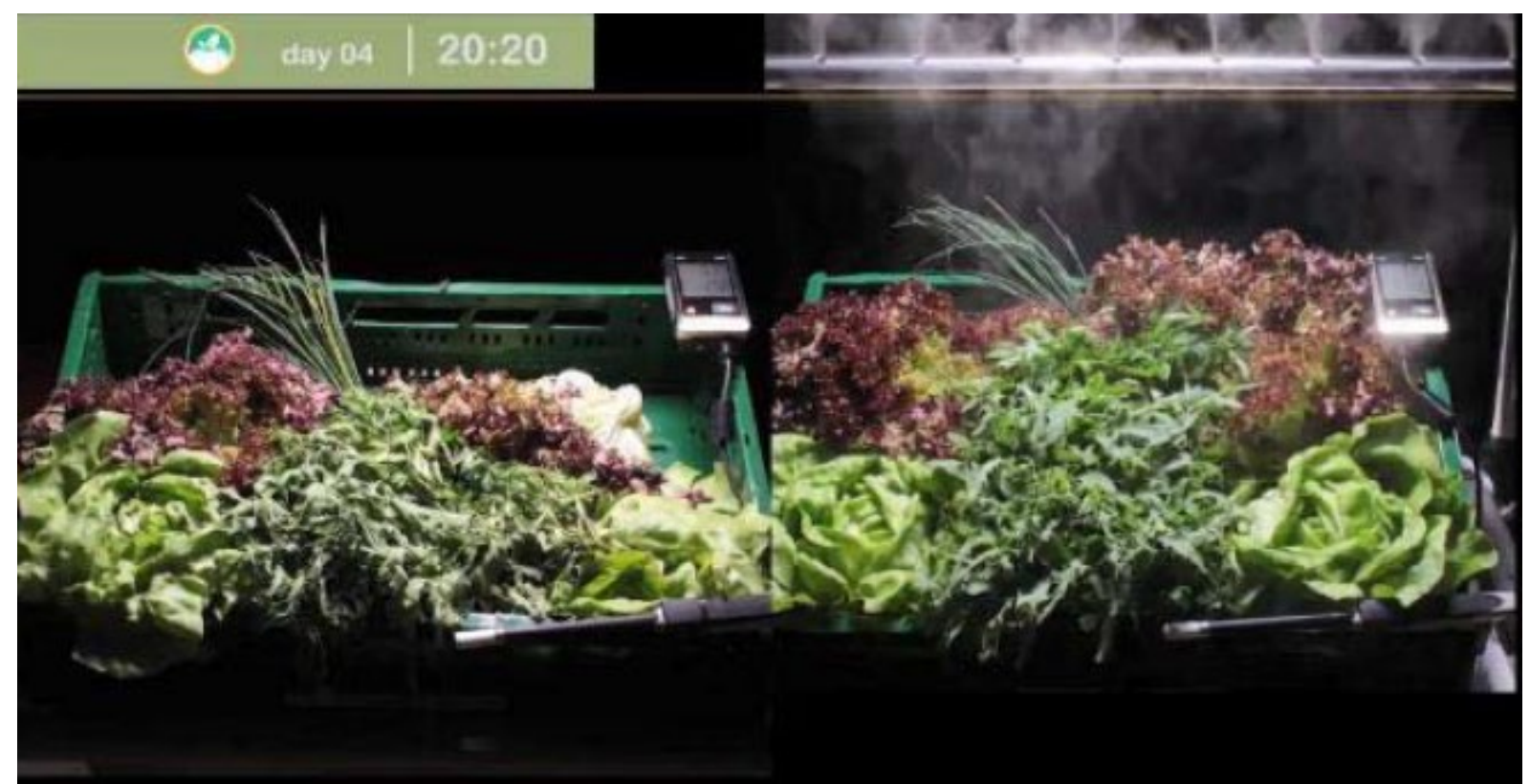

Figuur 7: Voorbeeld uit de test (op dag 4, verschil tussen controlegroep en inzet van verneveling) Bron: Fresh Demo, report D4.0 Report on all Fresh Demo tests, 2017

Voor de berekening van de kosten/opbrengsten werden de kosten voor investering, afschrijving, energiegebruik, watergebruik, en onderhoud afgezet tegen verhoogde omzet, terugdringen verspilling, vermindering in energiekosten, en vermindering van arbeidskosten (omdat nachtelijke terug koeling niet noodzakelijk is bij inzetten van verneveling).

Het project rapporteert op basis van de analyseresultaten de volgende voordelen:

Minder vochtverlies uit het verse product (tussen $25-70 \%$ )

Verlenging schap leven (2-5 dagen)

- Verbetering van smaak, kleur en kwaliteit

Terugdringen van derving/voedselverspilling $(-25 \% / € 5.200,-)$

Een aantal issues met betrekking tot het interpreteren van deze onderzoeksresultaten kunnen als volgt worden opgesomd:

$\rightarrow$ Het bevochtigingsconcept wordt gecombineerd met het inzetten van Formule5 (een zuurteregelaar die ook als een desinfectans wordt ingezet; de resultaten van de combinatie zijn beter dan die van verneveling alleen.

$\rightarrow$ Het betreft 'droge mist': de resultaten kunnen niet rechtstreeks worden doorgetrokken naar vernevelingstechnieken die op natte mist zijn gebaseerd.

$\rightarrow$ Het concept wordt ingezet direct naoogst tot en met het supermarkt schap. Wat de invloed is van verneveling op het supermarkt schap alleen is niet bekend. Vanuit kwaliteitsoptiek is een betere ingangskwaliteit van grote invloed op behoud van kwaliteit over de tijd. Het is goed mogelijk dat vooral het verbeteren van de bewaaromstandigheden tijdens naoogst transport en opslag via handel/distributiecentra invloed heeft op het verlengen van het schap leven.

$\rightarrow$ In het onderzoek is niet gekeken naar de huidige tijdsduur die het product op het schap doorbrengt. Het verlengen van schap leven (het toevoegen van resterende houdbaarheid met behoud van kwaliteit), kan leiden tot minder derving. 
2. Dieckmann, A., List, D., Zache, U. 1993. Cold Water Mist Humidification to Preserve the Quality of Fresh Vegetables During Retail Sale. LWT- Food Science and Technology vol. 26, issue 4, pp. 340-346.

Deze studie onderzocht de effecten van waterverneveling op het kwaliteitsbehoud van verse groenten op het supermarkt schap. De onderzochte producten zijn:
Veldsla uit Nederland
Kropsla uit Duitsland
Broccoli uit België
Witlof uit Nederland en België
Wortelen uit Duitsland.

De producten werden naoogst ongekoeld en onbehandeld, binnen 24 uur (of, in het geval van aankoop via veiling, na 48 uur) gedistribueerd naar de supermarkt winkels. Er wordt niet gemeld waar deze zich bevinden, wel dat het een lokale supermarktketen betreft. Gezien het feit dat de auteurs verbonden zijn aan een Duitse universiteit, zou dit kunnen wijzen op testen in Duitsland.

Op het schap werd verneveling ingezet ('water misting' door de KES-2000 techniek, een natte verneveling). De testen werden over 96 uur op het schap uitgevoerd. Gemeten kwaliteitsaspecten betroffen:

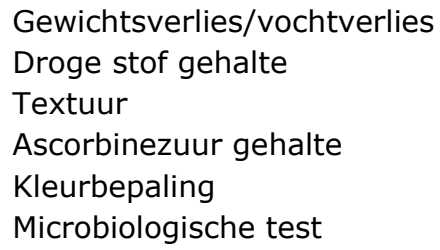

De resultaten werden vergeleken met conventionele uitstalling omstandigheden (droog/ambient) zonder verneveling. Alle benevelde producten ( 6 seconden sprayen, 20 minuten tussenpozen) lieten een sterk verminderd vochtverlies en lagere toename van droge stofgehalte zien. Het verschil was het grootste bij Veldsla, die zelfs in gewicht toenam gedurende de test $(+8 \%)$. Niet benevelde veldsla was al na 48 uur onverkoopbaar. Bij de andere producten was er tussen de 1-5\% minder vochtverlies. De textuur (stevigheid \& 'crispness') bleef langer bewaard. Er was ook een langzamere afname van vitamine Cgehalte (uitgedrukt in ascorbinezuur) waargenomen. Invloed op kleur werd niet opgemerkt. Zowel benevelde als niet-benevelde producten lieten een toename zien in het aantal micro-organismen, maar bleven beide binnen de grenzen van $0.5 \mathrm{log}$ cycles CFU/g, waardoor er geen gezondheidseffecten werden verwacht. Deze studie concludeert dat water verneveling het schap leven van deze plantaardige producten tot aan 72 uur kan verlengen, zonder ernstig kwaliteitsverlies.

\section{Brown, T., Corry, J., James, S., 2004. Humidification of chilled fruit and vegetables on retail display using an ultrasonic fogging system with water / air ozonation. International Journal of Refrigeration, vol. 27, pp. 861-868.}

Deze studie onderzocht het inzetten van natte ultrasone verneveling bij niet-verpakte groenten en fruit producten op het koelschap in supermarkt, en de invloed ervan op kwaliteit. Er werd vergeleken met conventionele, droge omstandigheden op het schap. De ingezette vernevelingstechniek (van Norman Pendred \& Co.) bevatte antibacteriële maatregelen, inclusief ozonering. Kwaliteit werd uitgedrukt in vochtverlies, visuele kwaliteit en microbiologische testen. Hoewel niet vermeld, is het aannemelijk dat het om testen in het Verenigd Koninkrijk gaat. De testen werden gedurende 7 dagen uitgevoerd. 
De geteste producten waren:

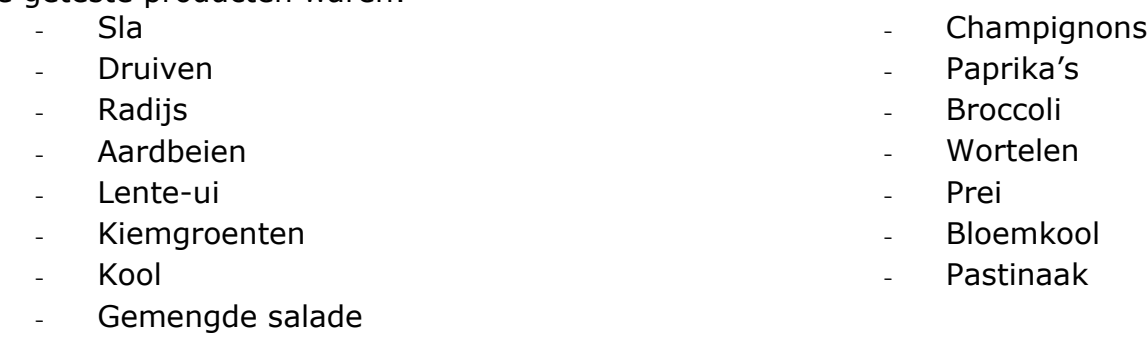

De producten uit de test- en controlegroep ondergingen vooraf hetzelfde traject van oogst tot belevering in de winkel, onder gekoelde, verpakte condities. De producten werden bij elkaar geplaatst in een verticaal koelmeubel ('cabinet'), verdeeld over verschillende hoogtes.

De studie vermeldt dat verneveling het gemeten gewichtsverlies bij champignons, broccoli en (groene) paprika vermindert. Na 7 dagen was dit respectievelijk 17.8, 3.0 en 1.7\%. Dit vochtverlies is voor alle producten (uitgezonderd radijs en aardbeien) ook subjectief gemeten door visuele waarneming. Hier werden de volgende verschillen waargenomen (fig.8):

\begin{tabular}{lll}
\hline \multicolumn{2}{l}{ Table 2} & \\
Subjectively judged retention of acceptable display appearance \\
\hline Appearance retention (days) & Wet & Dry \\
\hline Gem lettuce & 4 & 2 \\
Grapes & 7 & 4 \\
Spring onions & 7 & 4 \\
Pepper & 7 & 5 \\
Sprouts & 7 & 5 \\
Mushrooms & 4 & 2 \\
Strawberries & 4 & na \\
Radishes & na & 5 \\
Salad bowl & 4 & 2 \\
Carrots & 7 & 4 \\
Parsnips & 7 & 4 \\
Cauliflower & 7 & 3 \\
Broccoli & 7 & 3 \\
\hline
\end{tabular}

Figuur 8: Overzicht resultaten van subjectieve beoordeling van de visuele kwaliteit Bron: Brown et al, 2004

Ook verminderde verneveling de teruggang in visuele kwaliteit van het uiterlijk van de uitgestalde producten. Er werden geen negatieve effecten ten aanzien van microbiologische kwaliteit gevonden. Er worden in de studie geen uitspraken gedaan over bereikte houdbaarheid verlenging of het terugdringen van derving. Dit was ook niet in de onderzoeksopzet meegenomen. 


\subsubsection{Volgens de leverancier}

Er zijn onderzoeken gedaan naar productcategorieën die in meer of mindere mate baat zouden hebben bij verneveling. Deze worden door leveranciers van vernevelingstechniek ook gebruikt om aan geven welke producten (volgens hen) het meest in aanmerking komen voor verneveling ten behoeve van behoud van kwaliteit en vers perceptie. Een voorbeeld wat met enige regelmaat terugkomt in de deskresearch is die van Natural Misting, die hieronder wordt beschreven

\section{Naturalmisting.com}

Deze leverancier van droge-mist vernevelingstechniek op het supermarkt schap heeft eigen documentatie ontwikkeld die ingaat op welke producten al dan niet in aanmerking komen voor het inzetten van verneveling. Zij maken een onderverdeling naar de volgende producten:

1. Producten die aanmerking komen:

\begin{tabular}{|c|c|}
\hline - Venkel & - Groene mosterd \\
\hline Asperges & Rabarber \\
\hline Radijs & Meiraap \\
\hline Prei & waterkers \\
\hline Broccoli & Wortels \\
\hline Spruitjes & - Chinese sla \\
\hline - $\quad$ (Spits)kool & - $\quad$ Peterselie \\
\hline - Witlof & - $\quad$ Rode kool \\
\hline - $\quad$ Uien & - Raapstelen \\
\hline Sla & Verse Munt \\
\hline Spinazie & \\
\hline
\end{tabular}

2. Producten die optioneel behandeld kunnen worden:

(Fles)pompoen

Artisjok

Mais

Komkommer

Aubergine

Paprika

Bloemkool

Groene bonen 
3. Producten die bij voorkeur niet met verneveling behandeld worden:

Droge uien

Paddenstoelen/champignons

Tomaten

Aardappelen

Citrusvruchten

Zacht fruit (o.a. frambozen, bessen, bosvruchten)

Kiwi

Verse gember

Deze suggesties voor wel/optioneel/niet behandelen kunnen wijzen op de constatering dat niet alle producten even geschikt zijn. Waarom zij niet geschikt zijn, of welk onderzoek hieraan ten grondslag ligt wordt in de bedrijfsdocumentatie niet vermeld. Het kan gaan om negatieve effecten op de kwaliteit of houdbaarheid of juist een gebruik aan effect, waardoor het bedrijfseconomisch geen meerwaarde heeft om de techniek toe te passen.

\subsubsection{Andere maatregelen die kwaliteit en houdbaarheid beïnvloeden op het supermarkt schap}

Uiteindelijk blijft de vraag gerechtvaardigd of investeren in vernevelingstechniek effectief en efficiënt is. Deze keuze voor de supermarktondernemer moet worden genomen in het licht van andere condities en maatregelen die invloed hebben op kwaliteit.

\section{Shewfelt, R., Prussia, S., Sparks, S., 2009. Challenges in handling fresh fruit and vegetables. In: Postharvest handling, editors Shewfelt, R. \& Prussia, S. Elsevier books in the series Food Science and Technology.}

De auteurs stellen in dit boek dat de supermarkt is het meest zichtbaar is van alle stappen in de voedselketen, maar veelal de minst 'gecontroleerde' omstandigheden voor bewaring en uitstalling kent. De schappen zijn ontworpen om snelle en ook impulsieve aankopen bij de klanten te bevorderen, maar niet noodzakelijkerwijs ingericht/ontworpen op kwaliteitsbehoud. Bewaaromstandigheden (waaronder temperatuur, relatieve vochtigheid en belichting), samen uitstallen van moeilijk combineerbare producten, schap duur, en 'handling' door personeel en klanten hebben allemaal invloed op kwaliteit en aantrekkelijkheid voor de klant. Toevoegen van ijs of vernevelingstechnieken zijn voorbeelden van technieken die worden ingezet om kwaliteit te behouden. Shewfelt et al. stellen dat het bewerkstelligen van een hoge omloopsnelheid het meest effectief is om kwaliteitsverlies te verminderen.

Naast de door Shewfelt et al. genoemde omstandigheden, maakt het ook uit wat de ingangskwaliteit van het product is, het al dan niet aanwezig zijn van initiële besmettingen met schimmels of bacteriën, en de naoogst bewaar- en transportcondities. Koeling speelt hierbij een belangrijke rol, maar ook moet koude-schade worden voorkomen. Niet alle producten kunnen even goed tegen sterke koeling, denk daarbij aan zacht fruit en tropisch fruit 


\subsection{Perceptie consument}

Deze sectie gaat in op de stand van zaken in de literatuur in antwoord op de tweede onderzoeksvraag, die als volgt is geformuleerd:

2. Welke achterliggende aspecten rondom PERCEPTIE bij consumenten spelen een rol bij vernevelingstechniek op het supermarkt schap?

Consumenten kopen met al hun zintuigen, waarbij zicht, tast, geur zowel bewust als onbewust een rol spelen. Er wordt relatief veel onderzoek gedaan naar het aankoopgedrag van consumenten, in diverse settings, waaronder supermarkten. Hier spelen zowel contextuele, externe factoren (bijvoorbeeld kleur, schapindeling, plaatsing) als individuele, interne factoren (zoals merkvoorkeur, prijs gevoeligheid en dieetvoorkeuren) een rol (Gidlöf et al., 2017). Deze vragen alle om aandacht en spelen een rol tussen hoe de supermarkt zijn producten toont en hoe de consument daarop reageert. Uit onderzoek blijkt dat vooral het visuele aspect een grote rol speelt in aankoopgedrag. Het voorspelt grote mate voorspelt of een klant tot aankoop overgaat. Het (langer) bekijken van een product maakt het waarschijnlijker dat er daadwerkelijk tot aankoop wordt overgegaan. Deze visuele informatie voedt daarmee het beslismechanisme en daarmee dus het keuzegedrag. Het effect dat hierbij een rol speelt heet het 'gaze-cascade' effect (Glaholt \& Reingold, 2009).

Deze studies worden echter veelal uitgevoerd op basis van verpakkingskenmerken, waaronder informatie die wordt weergegeven op verpakkingen (zie o.a. Peschel \& Orquin, 2013) of plaatsing op het schap (zie o.a. Atalay et al., 2012), of informatievoorziening op diverse manieren in en rondom het schap.

Toch moet worden geconstateerd op basis van de uitgevoerde desk research dat er erg weinig wetenschappelijke kennis voorhanden is op het specifieke snijvlak tussen ervaren kwaliteit of vers perceptie van consumenten en het inzetten van vernevelingstechniek. Daarmee is de relatie tussen het inzetten van deze techniek of andere vormen van zichtbaar aanwezige technologie die invloed heeft op de kwaliteit van uitgestalde producten, noch de potentiële verlenging van de houdbaarheid die daarmee kan samenhangen grotendeels nog onbeschreven in de wetenschappelijke literatuur.

Het eerder genoemde onderzoek door Contronics bevatte ook een consumentenonderzoek, uitgevoerd bij klanten van 2 supermarktketens om een beeld te krijgen hoe de Nederlandse supermarktklant het inzetten van de techniek ervaart. Hoewel de steekproefgrootte niet wordt toegelicht, komen overwegend positieve reacties uit de bevraging naar voren. $92 \%$ was het opgevallen dat de vernevelingstechniek werd toegepast. 
Er werd ook gevraagd wat men van de mist vond. $22 \%$ vond het heel goed ,58\% goed, $5 \%$ niet zo goed, $2 @$ slecht en $13 \%$ had geen mening. Nadat men informatie had ontvangen over de techniek verschuift dit beeld naar $45 \%$ heel goed, $48 \%$ goed en $7 \%$ geen mening. De ontvangen informatie staat in figuur 9 hieronder.

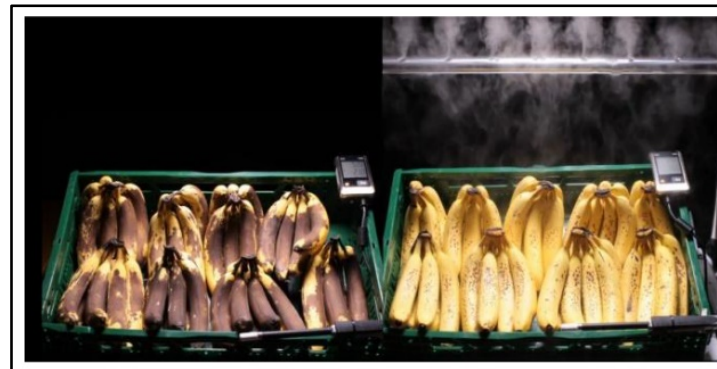

De supermarkt heeft de mist geïnstalleerd om voedselverspilling tegen te gaan. De mist is verneveld zuiver water, ze zorgt voor een betere kwaliteit en langere versheid van de groente en het fruit. Omdat de mist verdampt, stijgt de luchtvochtigheid en ontstaat er een natuurlijk koelend effect. De verse producten drogen nu niet meer uit, ze behouden langer hun kwaliteit en worden niet nat. Zo hoeft de supermarkt minder weg te gooien!

Figuur 9: Gebruikte informatie bij het voorlichten van respondenten.

Bron: Contronics Consumentenonderzoek 2018.

Opgetekende reacties op de mist zijn o.a.

Positief (81\%)

Het maakt de groenten- en fruitafdeling heel aantrekkelijk

Goed dat de supermarkt aandacht besteed aan voedselverspilling

Groenten en fruit zijn verser

Het ziet er gezond uit

Volgens mij blijven de kruidenplantjes groeien in de schappen

Negatief (19\%)

Het heeft toch geen effect als de producten nog zijn verpakt

Volgens mij staat het er voor de show

Ik snap niet at het doet

Vochtig 
Op de vraag of de respondenten het idee hebben dat de kwaliteit en versheid van de groenten en fruit is veranderd sinds de mist er is, konden de volgende antwoorden worden opgetekend (fig. 10):

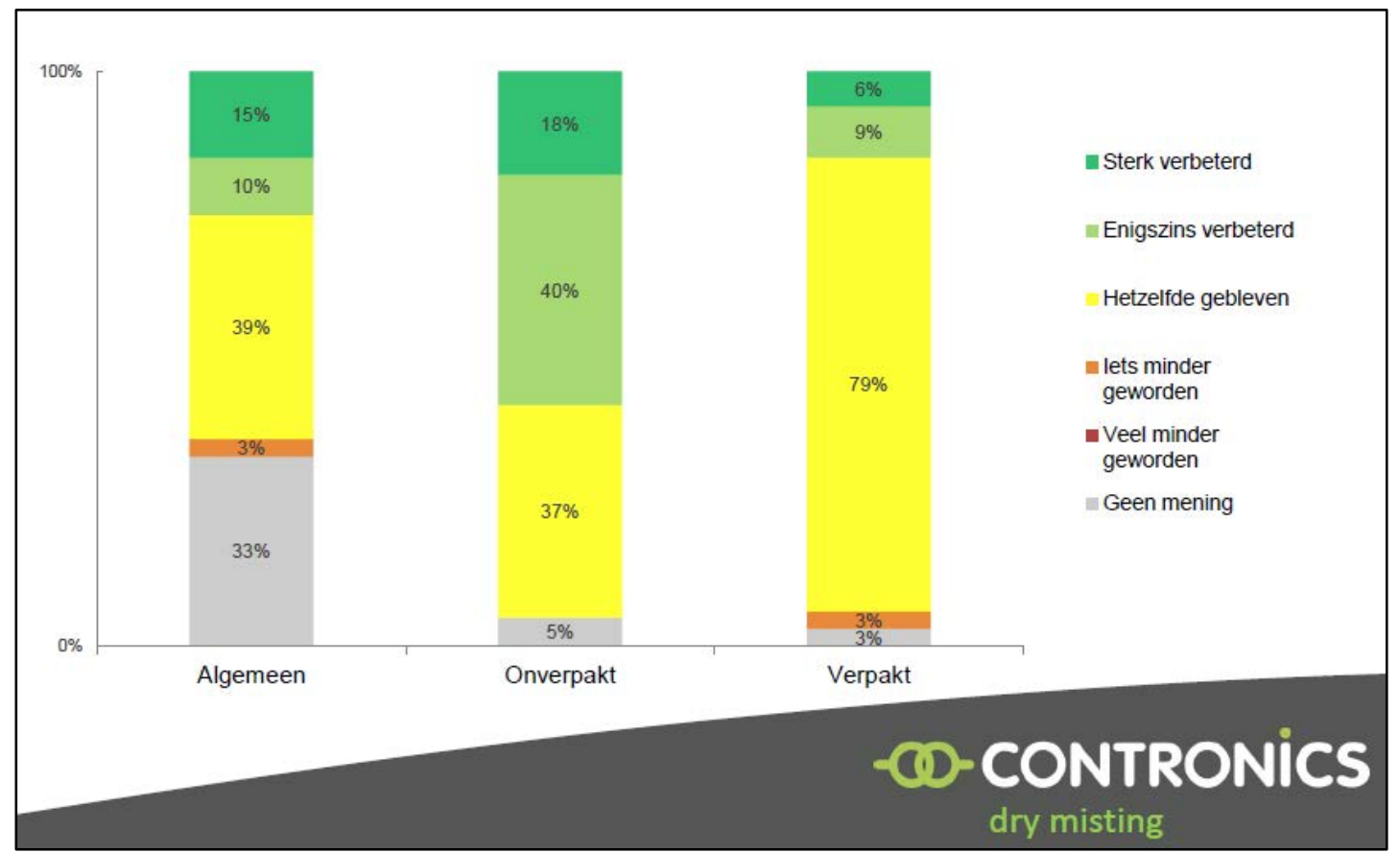

Figuur 10: Overzicht resultaten met betrekking tot vraag ervaring versheid \& kwaliteitsverbetering na inzet van mist op het supermarkt-schap.

Bron: Contronics Consumentenonderzoek 2018.

Vooral voor niet-verpakte producten lijkt men positieve effecten op kwaliteit en versheid te ervaren.

De kanttekening moet gemaakt worden dat dit consumentenonderzoek niet wetenschappelijk is opgezet en dat de resultaten niet door het gebruikelijke peer review proces zijn gegaan. Wel geven de bovenstaande aankomsten een aanzet tot het verder onderzoeken van de perceptie van de consument op het inzetten van vernevelingstechniek op het supermarkt schap. Op dit moment zijn er zo'n 11 Nederlandse supermarkten die deze techniek op het schap uittesten. 


\section{Discussie en vragen voor vervolgonderzoek}

De wetenschappelijke basis in de literatuur voor het beantwoorden van de onderzoeksvragen is gering. Het precieze snijvlak van onderzoek naar invloed van verneveling op houdbaarheidsverlening, terugdringen van derving in combinatie met consumentenperceptie is nauwelijks terug te vinden. Veel literatuur gaat in op de technische aspecten, of behandelt vooral de invloed op versproducten gedurende naoogst transport en bewaring. Toch kan voorzichtig worden opgemerkt dat toepassing in de praktijk niet afgeremd wordt door dit gebrek aan wetenschappelijke onderbouwing.

Een van de aspecten waardoor het waarschijnlijk is dat er weinig literatuur voor handen is, is het feit dat kwaliteit en houdbaarheid van versproducten is veelal product-specifiek zijn én context gevoelig. Er bestaan algemene richtlijnen, waaronder temperatuur en conditionering (o.a. relatieve vochtgehalte, ethyleengehalte, $02 / \mathrm{CO} 2$ gehalte) waarvan uit de Post-Harvest Technologie bekend is dat zij invloed hebben op kwaliteit en houdbaarheid. Veel hangt echter af van het specifieke product, en de specifieke omstandigheden van de hele keten van boer tot supermarkt schap. Het precieze 'bewijzen' van de efficiëntie en effectiviteit wordt daarmee een lastige puzzel. Wel een die kan bijdragen aan het vormgeven van maatregelen die effectief bijdragen aan het voorkomen van verspilling. Immers: het behouden van kwaliteit en een ruime houdbaarheid vergroten de kans dat geproduceerd voedsel daadwerkelijk geconsumeerd wordt.

Hoewel beide technieken voorkomen, lijkt droge mist de voorkeur te krijgen boven natte mist. Een teveel aan vocht kan leiden tot (versnelde) schimmelgroei en rot. Door specifieke productkenmerken treedt dit niet altijd of in dezelfde mate op bij alle AGF producten. Er bestaan gedocumenteerde (doch zeldzaam voorkomende) gevallen in de jaren ' 90 waarin een besmetting met de Legionella-bacterie plaatsvond. Deze was veelal voortkomend uit een bronbesmetting in de vernevelingsapparatuur (en daarmee een secundair effect), maar wel een die door een goede hygiëne en opvolging gebruikersvoorschriften van de vernevelingsapparatuur moet worden meegenomen. De techniek (en haar leveranciers) heeft ook stappen gemaakt om dit type besmettingen te voorkomen. Het ingaande water dient bacterie en coliform vrij te zijn (parameters voor 'schoon' water), maar ook de apparatuur zelf heeft invloed op het behoud van deze waterkwaliteit.

\section{De volgende veronderstellingen kunnen worden opgetekend op basis van het literatuuronderzoek:}

Algemeen: Het vermoeden bestaat dat de inzet van vernevelingstechniek op het supermarkt schap bij versproducten uit AGF-categorieën kan voordelen hebben ten opzichte van conventionele, ambient bewaarwijzen. De grootte van effecten zijn sterk product- en context afhankelijk.

Kwaliteit (oorzakelijk)

1. Verminderen/vertragen van vochtverlies uit het verse product

2. Verbetering/behoud van smaak, kleur en kwaliteit

Verlenging houdbaarheid (oorzakelijk)

3. Bijdragen aan het verlengen van schap leven

Vermindering verspilling (resultante)

4. Terugdringen van derving, doordat er minder uitval is vanwege bederf en een mogelijke bijdrage aan het verhogen van de omzet door kwaliteitsperceptie bij de consument en het verbeteren van de houdbaarheidsverbetering (meer tijd om een product te verkopen)

5. Verlagen van arbeidskosten omdat vernevelingstechniek de noodzaak tot nachtelijke koeling verminderd.

Perceptie bij consument

6. Verbeteren van 'Vers kwaliteit'- uitstraling, het aantrekkelijker ervaren van versproducten 
Er zijn uiteraard ook mogelijke nadelen die kunnen kleven aan de inzet van deze techniek

7. Mogelijke microbiologische/schimmelgroei, doordat de groeiomstandigheden door de vochtige omgeving verbeteren ten opzichte van conventioneel/ambient.

8. Technische afstelling komt vrij nauw, en de effectiviteit wordt mede bepaald door de vaardigheid van het betrokken personeel, onderhoud van de technische installaties, en het afstellen op de specifieke vereisten voor verschillende producten/productcategorieën.

De post-harvest engineering and phsysiology expertise van Wageningen Food \& Biobased Research richt zich in belangrijke mate op het leggen van verbanden tussen bewaar-, transport- en display omstandigheden met kwaliteit en houdbaarheid. Er is echter nog maar weinig vergelijkend onderzoek gedaan over de hele keten en de veelheid aan verkochte versproducten in Nederland, en hoe zich dat verhoudt op het supermarkt schap. Nog minder is bekend wat vernevelingstechniek doet met verlenging van houdbaarheid van het product bij de consument thuis. Voordelen zijn vooral beschreven ten opzichte van het terugdringen derving in de supermarkt.

Op basis van het literatuuronderzoek kan helaas geen uitspraak worden gedaan om supermarkten al dan niet aan te bevelen de techniek in te zetten in hun bedrijf. De uiteindelijke keuze ligt bij hen. Het streeft er vooral naar supermarktondernemers van het Vakcentrum te informeren over bevindingen uit de wetenschap.

Er liggen nog ruime kansen voor vervolgonderzoek, waarbij gedacht kan worden aan onder andere de volgende onderzoeksopzetten:

Empirische studie naar de mate van verlenging van houdbaarheid die kan worden bewerkstelligd op het supermarkt schap door het inzetten van vernevelingstechniek. Daarbij wordt een grote diversiteit aan versproducten onderzocht, en wordt ook gecontroleerd wordt voor andere contextfactoren, waaronder omgevingstemperatuur en ingangskwaliteit, evenals omstandigheden voor bewaring en transport eerder in de keten. Andere aspecten zoals invloed op het verminderen van derving in de supermarkt en de economische en milieu-impact van het inzetten van deze techniek, ook in vergelijking met de conventionele handelswijze kunnen ook worden meegenomen.

Opzetten en uitvoeren van representatief onderzoek met gebruikmaking van consumentenpanels naar de perceptie van versheid, kwaliteit, houdbaarheid en invloed op voorkomen van voedselverspilling, waarbij ook gekeken wordt naar het gedrag van de consument binnen het huishouden. Dit kan zowel in-situ, in een virtuele supermarkt-omgeving of middels online visual surveys worden gedaan. Ook een focus-groep opzet leent zich voor een dergelijk onderzoek, hoewel dan meer aandacht voor kwalitatieve resultaten wordt bereikt dan het nastreven van statistische onderbouwing van de resultaten.

Voor praktisch georiënteerd vervolgonderzoek kan overwogen worden om diverse ronde tafelsessies te organiseren waarbij supermarktondernemers, onderzoekers en vertegenwoordigers uit de techniek in gesprek gaan over de mogelijkheden, vragen, bedenkingen en overwegingen over deze techniek als maatregel voor het tegengaan van voedselverspilling. 


\section{Literatuur}

Atalay, A., Bodur ,H., \& Rasolofoarison, D., 2012. Shining in the center: central gase cascade effect on product choice. Journal of Consumer Research, vol. 39, no 4, pp. 848-866.

Brown, T., Corry, J., James, S., 2004. Humidification of chilled fruit and vegetables on retail display using an ultrasonic fogging system with water / air ozonation. International journal of refrigeration, vol. 27, pp. 861-868.

Contronics Consumentenonderzoek 2018.

Dieckmann, A., List, D., Zache, U. 1993. Cold Water Mist Humidification to Preserve the Quality of Fresh Vegetables During Retail Sale. LWT- Food Science and Technology vol. 26, issue 4, pp. 340-346.

Gidlöf, K., Anikin, A., Lingonblad, M., Wallin, A., 2017. Looking is buying. How visual attention and choice are affecdted by consumer preferences and properties of the supermarket shelf. Appetite, vol. 116 pp. 29-38.

Glaholt, M., Reingold, E., 2009. The time course of gaze bias in visual decision tasks. Visual Cognition, vol. 17, no 8, pp. 1228-1242.

Kennisonline, april 2011: http://edepot.wur.nl/165739

Peschel A. , Orquin, J., 2013. A review of the findings and theories on surface size effects on visual attention. Frontiers in Psychlogy, vol. 4. doi: 10.3389/fpsyg.2013.00902

Shewfelt, R., Prussia, S., Sparks, S., 2009. Challenges in handling fresh fruit and vegetables. In: Postharvest handling, editors Shewfelt, R. \& Prussia, S. Elsevier books in the series Food Science and Technology.

Tirawat, D., Flick, D., Mérendet, V., Erens, E., Laguerre, O., 2017. Combination of fogging and refrigeration for white asparagus preservation on vegetable stalls. Postharvest biology and technology, vol. 124, pp. 8-17.

Verschoor, J. \& Otma, E., 2010. Evaluation of Contronics "fresh in - fresh out" fresh displays. Report no. 1190.

www.fresh-demo.eu 



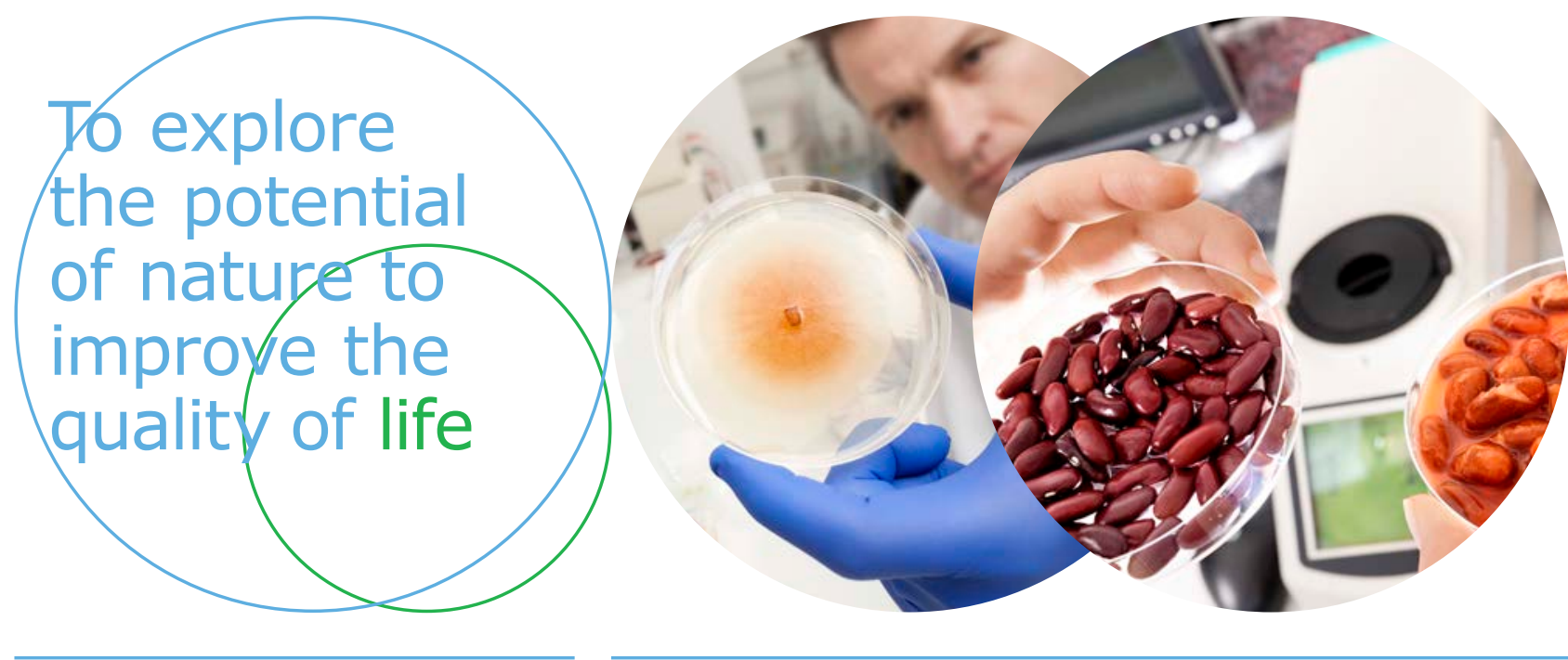

Wageningen Food \& Biobased Research Bornse Weilanden 9

6708 WG Wageningen

www.wur.nl/wfbr

info.wfbr@wur.nl

Rapport 1973

ISBN 978-94-6395-106-7
De missie van Wageningen University \& Research is 'To explore the potential of nature to improve the quality of life'. Binnen Wageningen University \& Research bundelen Wageningen University en gespecialiseerde onderzoeksinstituten van Stichting Wageningen Research hun krachten om bij te dragen aan de oplossing van belangrijke vragen in het domein van gezonde voeding en leefomgeving. Met ongeveer 30 vestigingen, 5.000 medewerkers en 10.000 studenten behoort Wageningen University \& Research wereldwijd tot de aansprekende kennisinstellingen binnen haar domein. De integrale benadering van de vraagstukken en de samenwerking tussen verschillende disciplines vormen het hart van de unieke Wageningen aanpak. 